\title{
Appraisal of Urban Trees Using Twelve Valuation Formulas and Two Appraiser Groups
}

\author{
Mauricio Ponce-Donoso, Óscar Vallejos-Barra, and Francisco J. Escobedo
}

\begin{abstract}
Monetary valuation using urban tree appraisals can be performed with formulas, a common practice in many countries. This study compares twelve parametric type formulas: Amenity Valuation of Tree and Woodlands (Helliwell), Standard Tree Evaluation Method (STEM), French Method, Italian Method, Tedesco, Norma Granada, Trunk Replacement Formula (CTLA), Burnley Method, Danish Method, Swiss Method, and two Chilean formulas used in Municipalities of Concepción, La Pintana, and Maipú (COPIMA Method), and Peñalolén Method. Formulas were then applied to 30 trees located in Santiago, Talca and Concepción, Chile.

Researchers used eight appraisers divided into two groups, according to senior-level and junior-level experience. Statistical differences were determined using the Kruskal-Wallis test of non-parametric variance, while Fisher's least significant difference test was used to identify homogeneous groups. The results show a wide dispersion of values that were high for "emblematic" trees and low for young or low-vigor trees.

Formula, type of appraisers, and inter-appraiser differences formed nine, two, and three groups, respectively. The lowest-appraised trees were obtained using the Danish and French Method, while the highest values were obtained with the Burnley, Helliwell, and STEM formulas. Although there were differences in tree value according to the type of appraiser, when comparing difference among appraisers, researchers found these were not due to experience level. Given the wide range of values found, the study authors cannot recommend any specific formula(s) for assessing urban trees, as results will depend on the variables of interest used in the formulas and their intended application and use.

Key Words. Arboriculture; Parametric Formulas; Tree Assessment; Tree Valuation; Urban Forest Benefits.
\end{abstract}

Urban trees are defined as trees found in areas located in urban or peri-urban areas (Tyrväinen et al. 2003), in residential and commercial sidewalks, parks, greenbelts, industrial parks, and vacant lots, among other land uses (Cordell et al. 1984). Different authors acknowledge their contribution to the sustainability of cities and their role as an economic asset (Tyrväinen et al. 2003; Konijnendijk et al. 2004; Ponce-Donoso et al. 2009). While recognizing the difficulty in determining the monetary value of urban trees, there are several available methods for calculating this value (Caballer 1999; Tyrväinen 2001; Watson 2002; Price 2003; Grande-Ortiz et al. 2012). The most common appraisal method for monetary valuation of urban trees is using formulas (Watson 2001), which are commonly of two types: parametric and capitalization. Parametric, also known as multiplication, is defined as the quantification of one or more variables, including both structural and other subjective ones (e.g., aesthetics, botanical, location, or significance), which, as recommended, should be performed by experienced appraisers, as they are not always accurate (Price 2003). Capitalization formulas use more conventional econometric methods (Grande-Ortiz et al. 2012). Chueca (2001) has indicated that these formulations require that the subjectivity of the variables used be reduced in the applied formulas. Hence, some professionals recommend the use of capitalization type formulas for their simplicity, while others prefer the parametric formula, stating that it better reflects the true total economic value of the tree (Petersen and Straka 2011; Grande-Ortiz et al. 2012).

Currently, several studies are assessing the different ecosystem services provided by urban trees, such as property value increases, carbon sequestration, reduction of noise and pollutants, energy use savings, and others for different conditions and 
contexts (Dobbs et al. 2011; Roy et al. 2012; Haase et al. 2014; Escobedo et al. 2015). Likewise, available formulas that allow for the monetary valuation of these urban forest ecosystem services are commonly used in methods and models such as i-Tree (i-Tree 2012) and CAVAT (Neilan 2010).

However, these valuation formulas are based on different assumptions and approaches that vary by form, application, and in the final total monetary value of the tree (Randrup 2005). For example, some of these formulas are based on the cost of replacing a damaged or vandalized tree (i.e., replacement cost), and are adjusted according to commonly used factors, such as tree vitality, damage type, location, aesthetics, overall amenities, age, and even provision of environmental services, which finally deliver a comparable monetary value (Moore and Arthur 1992; CTLA 2000; Helliwell 2008; Ponce-Donoso et al. 2013; Östberg and Sjögren 2016). Some of these formulas include the Trunk Formula Method from the Council of Tree and Landscape Appraisers of the United States (CTLA 2000), Burnley Method of Australia (Moore and Arthur 1992), Amenity of Trees and Woodland of the United Kingdom or Helliwell Method (Helliwell 2008), Norma Granada of Spanish Association of Parks and Public Gardens (AEPJP 2007), and the Standard Tree Evaluation Method (STEM) of New Zealand (Flook 1996).

These various formulas will indeed have different levels of acceptance and validity even within their country of origin. The Helliwell Method, for example, is accepted and regularly used in the UK, as is the CTLA Method in the U.S. and Canada (Cullen 2005; Cullen 2007). But even within these countries their acceptance is not complete among all legal contexts and by individual tree appraisers because of the variability in the range of estimated values (Watson 2001; Watson 2002). Furthermore, since these formulas were developed for use in primarily temperate, industrialized, English-speaking countries, the factors used might not be relevant to different cultural, ecological, and socio-political contexts (i.e., tree forms and species from tropical environments, land-use definitions from emerging countries, culturally specific tree maintenance practices, translation of English-language variables).

Accordingly, several international studies have applied parametric and capitalization valuation formulas in different contexts, such as Argentina (Contato-Carol et al. 2008), Brazil (Leal et al. 2008), Chile (Ponce-Donoso et al. 2012; Ponce-Donoso et al. 2013), Spain (Grande-Ortiz et al. 2012), the United States (Watson 2002), Finland (Tyrväinen 2001), Hungary (Hegedüs et al. 2011), as well as for applied extension education programs in these English-speaking countries (Harris 2007; Sarajevs 2011). As such, these different formulas can be used for different applications internationally, including damage assessments, legal claims or investment values, and replacement and damage costs, among others (Grande-Ortiz et al.2012; Östberg and Sjögren 2016).

However, the appraised values will be influenced by how, and the purposes for which the formulas are used. The STEM formula is commonly used in its existing form, while some formulas are derived from others-such as the CAVAT, which was derived from the Helliwell Method (Randrup 2005), and the French Method, which originates from the Swiss Method via an adaptation that accounts for maintenance of ornamental species (Contato-Carol et al. 2008). Similarly, the CTLA Method has inspired the Danish Method (Randrup 2005). In South America, different appraisal methods are applied inconsistently, and as in other regions, their acceptance by local judges has been varied (Contato-Carol et al. 2008; Ponce-Donoso et al. 2009). As a result, there is a need to quantitatively evaluate these different valuation formulas and their parameters or variables under different contexts for their use in urban forest management and legally related activities.

Moreover, studies highlight the subjectivity of the appraisers when applying these formulas. The subjectivity of which results in high variability in values, in particular with the Helliwell Method, whereas with CTLA and Burnley Methods, values have been reported to be lower (Watson 2002). Ponce-Donoso et al. (2012) found high values for the STEM formula, average values for CTLA, and low values with the Burnley Method. Contato-Carol et al. (2008) noted that the Swiss and Finnish Methods had higher values, while similar mid-range values were obtained with both the CTLA and French Methods, which are due to the inclusion of aesthetics and ornamental variables, as previously mentioned; although, in larger specimens, the CTLA Method presented higher values than did the French Method. The commonly used CTLA 
Method's validity has been questioned because of its subjectivity, which leads to statistically significant differences (Cullen 2007) and mid-range monetary values when compared with other formulas (Contato-Carol et al. 2008; Ponce-Donoso et al. 2012). Further, the CTLA Method showed lower values when compared to other methods, indicating the need to test the different methods outside their country of origin because extreme differences are not always obvious (Watson 2002). GrandeOrtiz et al. (2012) does, however, indicate that the CTLA Method can be widely used because of its low degree of difficulty, thus providing a comparatively good and available method for international use.

Therefore, the objective of this study was to analyze the monetary values obtained by the application of these twelve urban tree assessment formulas. The study was done using eight different appraisers with varied backgrounds, separated into two groups. Researchers also used three different cities in central Chile to develop three scenarios. This quantitative approach can be used to develop a single formula for central Chile, since currently eight different formulas are being used in ten municipal courts in this region, resulting in broad and disparate results (Ponce-Donoso et al. 2012).

\section{MATERIALS AND METHODS}

The study analyzed public urban trees in three Chilean cities. The first city was the Municipality of Santiago, located in the Metropolitan Region, with an elevation of $599 \mathrm{~m}$ above sea level, with an area of $22.4 \mathrm{~km}^{2}$, and 200,800 inhabitants. The second city was Talca, located in the Maule Region at $102 \mathrm{~m}$ above sea level, with an area of $232 \mathrm{~km}^{2}$ and 201,800 inhabitants. Finally, the third city considered in the study was Concepción, located in the Bio-Bio Region, $12 \mathrm{~m}$ above sea level with an area of $221.6 \mathrm{~km}^{2}$ and 216,100 inhabitants (NCL 2013).

Following conventional formula methods, 30 trees were selected, representing a total of 16 tree species (Table 1). The design was based on eight different appraisers, consisting of foresters and agronomists, who were separated into two groups. One group was made up of professional experts with at least five years' experience (Senior Group, $\mathrm{SG}$ ), while the other group consisted of professionals with no experience in tree valuation (Junior Group, JG). All participants received the same
Table 1. Characteristics of the appraised trees in Santiago, Talca, and Concepción, Chile.

\begin{tabular}{|c|c|c|c|}
\hline Tree $^{z}$ & Scientific name & Age (years) & Location $^{y}$ \\
\hline 1 & Melia azedarach L. & 30 & MS \\
\hline 2 & Gleditsia triacanthos $\mathrm{L}$. & 30 & ST \\
\hline 3 & Acacia dealbata Link & 30 & MS \\
\hline 4 & Acer speudoplatanus L. & 40 & MS \\
\hline 5 & Acer negundo L. & 20 & MS \\
\hline 6 & Platanus orientalis $\mathrm{L}$. & 30 & MA \\
\hline 7 & Fraxinus excelsior $\mathrm{L}$. & 50 & MS \\
\hline 8 & Catalpa bignonioides Walt. & 75 & SQ \\
\hline 9 & Liquidambar styraciflua $\mathrm{L}$. & 9 & SS \\
\hline 10 & Koelreuteria paniculata Laxm. & 35 & MA \\
\hline 11 & Acer negundo L. & 24 & MS \\
\hline 12 & Ailanthus altissima (Mill.) Swingle & 25 & $\mathrm{PK}$ \\
\hline 13 & Ginkgo biloba L. & 111 & SQ \\
\hline 14 & Liquidambar styraciflua L. & 7 & SS \\
\hline 15 & Catalpa bignonioides Walt. & 25 & MS \\
\hline 16 & Quercus robur $\mathrm{L}$. & 60 & PK \\
\hline 17 & Acacia melanoxylon R. Br. & 28 & SQ \\
\hline 18 & Platanus orientalis L. & 100 & MS \\
\hline 19 & Betula pendula Roth & 12 & MS \\
\hline 20 & Acacia dealbata Link & 32 & SS \\
\hline 21 & Quercus robur $\mathrm{L}$. & 60 & SQ \\
\hline 22 & Liquidambar styraciflua L. & 45 & MS \\
\hline 23 & Acer negundo L. & 45 & SS \\
\hline 24 & Acer pseudoplatanus L. & 72 & PK \\
\hline 25 & Fraxinus americana $\mathrm{L}$. & 40 & PK \\
\hline 26 & Platanus orientalis $\mathrm{L}$. & 80 & MS \\
\hline 27 & Acacia melanoxylon R. Br. & 35 & MS \\
\hline 28 & Betula pendula Roth & 20 & SQ \\
\hline 29 & Ailanthus altissima (Mill.) Swingle & 35 & SQ \\
\hline 30 & Catalpa bignonioides Walt. & 25 & $\mathrm{PK}$ \\
\hline
\end{tabular}

instructions on the use of tree appraisal formulas, resulting in a total of 1,440 valuation appraisals.

The field work was conducted during the southern latitude summer months of December 2013 and February 2014, when the trees exhibited the best conditions for appraisal. Both biometric variables and those related to the aesthetic, condition, and location were measured and appraised. Selling prices were collected in local wholesale and retail nurseries, as well as annual maintenance costs reported by the Municipality of Talca, and supplemented with information from the Municipalities of Santiago and Concepción. The maintenance cost was calculated based on the annualized costs, including pruning, pest control, watering, and others. The price of the species in the nurseries was based on the average prices in both retail and wholesale markets.

The formulas analyzed in this study were selected with consideration to the best performance for valuation of a tree within a public-use area in a municipality, as well as by its speed of implementation and calculation, efficiency and effective- 
ness in data collection, and overall simplicity to appraisers. The formulas are described as follows:

The Municipalities of Concepción, La Pintana, and Maipú of Chile (refereed to hereafter as the COPIMA Method; Ponce-Donoso et al. 2009) use the following formula:

$$
\text { Value }(€ E U R)=\left(A{ }^{*} B{ }^{*} C^{*} D\right) / 10
$$

where $\mathrm{A}=$ price of species at the local market, $\mathrm{B}=$ aesthetic and condition value of the tree, $\mathrm{C}=$ situation index, and $\mathrm{D}=$ dimension index.

Municipality of Peñalolén of Chile Method (Ponce-Donoso et al. 2009) is as follows:

$$
\text { Value }(€ E U R)=0.2{ }^{\star} e+A{ }^{\star} B{ }^{*} V A
$$

where $\mathrm{A}=$ location factor, $\mathrm{B}=$ tree condition as a percentage of the damage present, $\mathrm{e}=$ age of the species, and VA $=$ tree value according to species and age.

Amenity Valuation of Tree and Woodlands, referred to as the Helliwell Method (Helliwell 2008), estimates the visual amenities based on a point range from 1.0 to 4.0, which accounts for seven factors:

$$
\begin{aligned}
& \text { Value }(€ E U R)=\text { tree size * useful life expectancy } \\
& { }^{*} \text { space importance }{ }^{*} \text { presence of other trees } \\
& { }^{*} \text { relation to other factors }{ }^{*} \text { shape }{ }^{*} \text { monetary factor }
\end{aligned}
$$

The Standard Tree Evaluation Method, known as STEM in New Zealand (Flook 1996), uses a point system based on 20 attributes ( 3 to 27 points each), characterizing a tree's condition, amenities, and special features of notability:

$$
\begin{aligned}
& \text { Value }(€ E U R)=[\text { total points }(540 \text { possible }) * \\
& \text { wholesale cost }+ \text { plantation cost }+ \text { maintenance } \\
& \text { cost }{ }^{*} \text { retail conversion factor }(\text { suggested } 2)
\end{aligned}
$$

The French Method (Ferraris 1984) corresponds to a method that provides an index related to the maintenance and care of the tree. It is based on Swiss Method but includes an additional factor to set a monetary value in parks and private gardens:

$$
\text { Value }(€ E U R)=E^{*} B{ }^{*} U^{\star} D
$$

where $\mathrm{E}=$ species and variety index, based on the reference price in the nursery, $B=$ health and aesthetic index, $\mathrm{U}=$ location index, and $\mathrm{D}=$ dimension index.
The Italian Method (Fabbri 1989) is as follows:

$$
\text { Value }(€ E U R)=P^{*} I^{*} S{ }^{\star} C
$$

where $\mathrm{P}=$ price of the same species in local nurseries; $\mathrm{I}=$ reflects the health and appearance of the tree; $\mathrm{S}$ = location index, rural or urban; and $\mathrm{C}=$ size index.

The Tedesco Method, from Italy (Bernatzky 1978), is as follows:

$$
\text { Value }(€ E U R)=V b{ }^{\star} I D * I P * I C{ }^{\star} I I A * I E * I R
$$

where $\mathrm{Vb}=$ basic value $1 / 10$ of market price for tree $10 \mathrm{~cm}^{2}$ of basal area; ID = dimension index in function of DAP or circumference; IP = position index; IC $=$ condition index, including spacing between trees, tree development, condition, and damage; IIA = environmental compatibility index, which considers variables, such as insertion into the landscape, compatibility with the soil type, and execution of the planting; IE = age index, which is related to the age of the tree that exceeds the average age of the species; and IR = reduction index due to stem damage.

The Granada Norm of the Spanish Association of Public Parks and Gardens (Norma Granada; AEPJP 2007) is a formula for a non-replaceable tree, and corresponds to:

$$
\text { [8] Value }(€ E U R)=\left(V b{ }^{*} E l s\right) *(1+E l e)
$$

where $\mathrm{Vb}=$ basic value of the tree, which is determined by the function $\omega^{*} \mu^{*}\left(0.0059 * \mathrm{p}^{2}+0.0601 *\right.$ $\mathrm{p}-0.324) . \omega=$ updated coefficient corresponding to the species, fixed for each climate zone according to Köppen; $\mu=$ soil corrector coefficient; $\mathrm{p}=$ perimeter of the trunk $1 \mathrm{~m}$ above the ground. Els = intrinsic factors of the tree (roots, trunk, main structural branches, sub-branches and terminal, leaves), and Ele $=$ tree extrinsic factors (aesthetic and functional, representativeness and rarity, situation).

The Trunk Replacement Formula from the Council of Tree and Landscape Appraisal, the CTLA Method of the United States (CTLA 2000), considers the area of the cross section of the trunk, $1.4 \mathrm{~m}$ over the ground level, multiplied by a value based on the cost of the regional species available in local nurseries. The value is then multiplied by corrector indices (species, condition, and location) to reduce or maintain this value: 
[9]

Value $(€ E U R)=\left(\right.$ trunk area $\left(\mathrm{cm}^{2}\right) *$ basic price $\left.\mathrm{cm}^{2}\right){ }^{*}$ species ${ }^{*}$ location ${ }^{*}$ condition

where the trunk area is expressed in $\mathrm{cm}^{2}$ and the basic price is expressed per unit of $\mathrm{cm}^{2}$. The species factor relates attributes of the tree associated with tree growth, life expectancy, adaptability to environmental conditions, maintenance requirements, and other amenities. The condition is related to the characteristics of the health and vigor of the tree. The location factor corresponds to the location of the tree in the city.

The Burney Method of Australia (Moore and Arthur 1992) is as follows:

$$
\begin{aligned}
& \text { Value }(€ E U R)=\text { tree volume }{ }^{*} \text { base value }{ }^{*} \text { life } \\
& \text { expectancy }{ }^{*} \text { shape and vigor }{ }^{*} \text { localization }
\end{aligned}
$$

where a number of points related to the volume of the tree are assigned, which correspond to an inverted cone, including the base value, which is the cost per cubic meter in retail nurseries, and other shape factors, vigor, and location.

The Danish Method (Randrup 2005) is as follows:

$$
\text { Value }(€ E U R)=B{ }^{*} H^{*} L^{*} A
$$

where $\mathrm{B}=$ base, which is expressed as $\mathrm{E}+(\mathrm{Pn} /$ $\mathrm{Cn}) *(\mathrm{Cd} / \mathrm{Cn})$, where $\mathrm{E}=$ costs of establishing value, $\mathrm{Pn}=$ price of a new tree, $\mathrm{Cn}=$ circumference of a new tree, and $\mathrm{Cd}=$ circumference of the evaluated tree; $\mathrm{H}=$ the health index, which is expressed as the condition of $(\mathrm{r}+\mathrm{t}$ $+r p+r s+f) / 25$, being roots $(r)$, trunk $(t)$, main branches (rp), secondary branches and twigs ( $r s$ ), leaves and buds (f); $\mathrm{L}=$ index location, which is expressed as $(\mathrm{n}+\mathrm{a}+\mathrm{ve}+\mathrm{v}+\mathrm{F})$ / 25, where natural ecological adaptation is ( $\mathrm{n})$, architecture (a), aesthetic value (ve), visibility (v) and environmental factors (F); and $\mathrm{A}=$ age index, which is expressed as $[((b-a) * 2) / b]-$ 2 , where $\mathrm{a}=$ current age and $\mathrm{b}=$ life expectancy.

The Swiss Method (Ferraris 1984) is as follows:

$$
\text { Value }(€ E U R)=P b^{*} I D{ }^{*} I P^{*} I E R{ }^{*} I R
$$

where $\mathrm{Pb}=$ base price; ID $=$ dimension index in function of the circumference trunk; IP = location index, which varies from the center of the city to a rural area; IER = aesthetic index and sanitary condition, which is related to vegetative vigor; and IR = reduction due to damage index, which is applied as a percentage of the trunk.

For the statistical analysis, researchers used both mean and median values to better reduce the effects of outliers. The following hypotheses were used to account for sources of variation such as the specific valuation formulas used, type of appraisers used, and inter- and intra-appraiser comparisons:

- Ho: $a i=a j / i \neq j$; (i.e., there are no statistically significant differences between the medians of the variation sources).

- Ho: $\alpha i \neq \alpha j / i \neq j$; (i.e., there are statistically significant differences between the medians of the variation sources).

Analyses of variance (ANOVAs) were used to determine if there were statistically significant differences between the sources of variation. The assumptions of homoscedasticity and normality were not met in all cases because of a high coefficient of variation (209.26\%). Similarly, despite the transformation of data, the bias and standardized kurtosis were high (143.20 and 704.48, respectively), exceeding Kirk's (1995) preset limit value of 2.0. In these cases, the non-parametric ANOVA KruskalWallis (Conover 1999) was used, as it is less sensitive to the presence of atypical values.

Both the data obtained from the SG and JG experience groups were ranked, according to their position in the ascending order of the data; with 1 having the lowest valuation and ranking, and 2,880 the highest, while the intermediate rankings corresponded to intermediate values for each group. Statistically significant differences were found between sources of variation, so the least significant difference test (DMS; $P \leq 0.001$ ) was applied (Conover 1999). Also, an analysis of nonparametric variance was separately conducted for each of the formulas to better observe the variability among them. Microsoft ${ }^{\oplus}$ Excel $^{\oplus}$ Version 2003 and Statgraphics Centurion for Windows ${ }^{\oplus}$ (StatPoint Technologies, Inc., Warrenton, Virginia, U.S.) were used for all statistical analyses. 


\section{RESULTS}

Table 2 shows the results of the average values for each of the analyzed formulas. According to the non-parametric Kruskal-Wallis analysis, the results show statistically significant differences between the median ranking in all sources of variation. In the formulas, the value was $1,235.23(P \leq 0.00)$; 4.30 was obtained between type of appraisers $(P \leq 0.04)$, and 14.97 between all appraisers $(P \leq 0.04)$.

Researchers also identified distinct homogeneous groups of formulas and appraisers as determined by the LSD test (Table 3 ). The formula conform nine groups overall, indicating heterogeneous and dispersed values according to the ranking, while there were two different groups for appraiser. When analyzing according to appraiser, three distinct groups were found, confirming that experience is indeed a source of differentiation (Table 3 ).

The median and the degree of dispersion of the ranking system for all formulas, experience of appraisers, and according to individual appraiser, are shown in Figure 1. Trends are

Table 2. Valuation results using 12 different urban tree appraisal formulas in central Chile (average in \$USD).

\begin{tabular}{|c|c|c|c|c|c|c|c|c|c|c|c|c|}
\hline Tree & $\begin{array}{l}\text { Danish } \\
\text { method }\end{array}$ & $\begin{array}{l}\text { French } \\
\text { method }\end{array}$ & CTLA & $\begin{array}{l}\text { Swiss } \\
\text { method }\end{array}$ & $\begin{array}{l}\text { Peñalolén } \\
\text { method }\end{array}$ & $\begin{array}{l}\text { Italian } \\
\text { method }\end{array}$ & COPIMA & $\begin{array}{l}\text { Norma } \\
\text { Granada }\end{array}$ & $\begin{array}{l}\text { Tedesco } \\
\text { method }\end{array}$ & $\begin{array}{l}\text { Helliwell } \\
\text { method }\end{array}$ & STEM & $\begin{array}{l}\text { Burnley } \\
\text { method }\end{array}$ \\
\hline 1 & 160.9 & 184.9 & 234.3 & 266.4 & 479.9 & 445.7 & 439.0 & $3,257.8$ & $1,078.1$ & $2,554.5$ & $1,871.8$ & $1,905.8$ \\
\hline 2 & 214.5 & 204.5 & 130.0 & 481.8 & 479.9 & 558.6 & 685.1 & 613.6 & $2,028.2$ & $4,057.3$ & $4,334.5$ & $8,360.1$ \\
\hline 3 & 243.4 & 361.4 & 320.5 & 644.4 & 479.9 & 777.9 & 657.1 & $1,661.4$ & $2,802.2$ & $4,282.7$ & $3,395.3$ & $4,940.1$ \\
\hline 4 & 196.0 & 233.6 & 301.4 & 503.8 & 639.9 & 579.5 & 874.5 & $1,052.9$ & $2,167.4$ & $9,128.8$ & $3,196.5$ & $4,479.5$ \\
\hline 5 & 106.1 & 51.0 & 39.0 & 90.9 & 319.9 & 141.3 & 305.3 & 225.7 & 262.7 & $3,806.9$ & $1,998.6$ & $2,983.4$ \\
\hline 6 & 176.2 & 157.3 & 250.6 & 389.9 & 479.9 & 506.1 & 619.7 & 981.7 & $1,415.5$ & $6,987.5$ & $4,100.8$ & $6,912.7$ \\
\hline 7 & 167.7 & 183.5 & 284.7 & 430.9 & 799.9 & 515.6 & 543.4 & $1,043.0$ & $1,626.5$ & $4,032.2$ & $2,223.0$ & $3,324.7$ \\
\hline 8 & 340.3 & 977.4 & $1,514.9$ & $1,168.3$ & $1,199.7$ & $1,687.8$ & $1,765.5$ & $3,643.2$ & $6,220.1$ & $6,480.4$ & $4,044.3$ & $4,028.2$ \\
\hline 9 & 205.8 & 80.4 & 48.6 & 219.0 & 144.0 & 217.1 & 234.2 & 346.8 & 324.4 & $8,790.8$ & $5,000.3$ & $11,339.1$ \\
\hline 10 & 351.8 & 381.0 & 739.4 & 985.1 & 559.9 & $1,125.1$ & $2,459.7$ & $1,307.8$ & $3,391.6$ & $3,731.7$ & $9,002.2$ & $11,957.7$ \\
\hline 11 & 163.5 & 271.9 & 307.4 & 382.9 & 383.9 & 731.9 & 752.3 & $1,753.5$ & $1,681.0$ & $3,418.6$ & $2,075.6$ & $1,762.3$ \\
\hline 12 & 316.1 & 635.1 & 307.4 & $1,046.9$ & 399.9 & $1,367.7$ & $1,221.2$ & $2,494.0$ & $7,561.6$ & $35,839.4$ & $2,481.2$ & $2,017.1$ \\
\hline 13 & $1,011.9$ & $2,503.4$ & $12,415.1$ & $4,643.6$ & $1,775.6$ & $5,271.4$ & $5,931.4$ & $36,656.1$ & $39,878.2$ & $40,347.4$ & $10,508.3$ & $5,024.7$ \\
\hline 14 & 210.1 & 68.2 & 69.4 & 206.0 & 111.9 & 217.1 & 301.6 & 363.5 & 264.4 & $6,593.1$ & $5,595.8$ & $12,967.4$ \\
\hline 15 & 86.9 & 98.7 & 70.5 & 172.5 & 399.9 & 306.1 & 568.4 & 610.1 & 629.5 & $1,540.3$ & $2,678.3$ & $1,305.7$ \\
\hline 16 & 367.7 & $1,095.2$ & $2,965.1$ & $1,097.7$ & 959.9 & $2,665.8$ & $2,643.4$ & $26,613.0$ & $19,947.3$ & $5,810.4$ & $6,370.4$ & $3,770.6$ \\
\hline 17 & 206.6 & 229.9 & 424.9 & 580.5 & 447.9 & 645.1 & 688.4 & $2,938.8$ & $2,305.5$ & $10,143.2$ & $2,295.2$ & $4,116.0$ \\
\hline 18 & 501.6 & $1,449.5$ & $4,580.5$ & $2,294.5$ & $1,599.6$ & $2,745.2$ & $4,107.7$ & $12,131.3$ & $16,144.5$ & $25,044.9$ & $5,897.5$ & $1,509.2$ \\
\hline 19 & 123.0 & 30.9 & 26.5 & 65.5 & 191.9 & 88.7 & 116.4 & 257.7 & 149.6 & $2,028.7$ & $2,697.5$ & $4,864.0$ \\
\hline 20 & 101.9 & 40.1 & 447.4 & 525.6 & 511.9 & 758.7 & 827.9 & $2,134.5$ & $1,279.5$ & $1,051.9$ & $2,503.4$ & $1,932.6$ \\
\hline 21 & 311.2 & 622.6 & 754.3 & 795.2 & 959.9 & $1,415.1$ & $1,336.9$ & $5,006.2$ & $4,889.7$ & $9,091.3$ & $6,964.7$ & $7,954.8$ \\
\hline 22 & 531.7 & $1,190.9$ & 2,996.9 & $3,102.6$ & 719.9 & $3,473.5$ & $3,405.3$ & $11,845.7$ & $13,575.8$ & $10,030.5$ & $6,414.5$ & $7,944.0$ \\
\hline 23 & 120.8 & 80.0 & 141.2 & 220.1 & 719.9 & 253.8 & 436.1 & 578.2 & $1,005.2$ & $8,809.6$ & $2,152.7$ & $2,685.1$ \\
\hline 24 & 389.9 & 802.1 & $2,281.2$ & $1,068.6$ & $1,151.8$ & $1,576.1$ & $1,574.3$ & $7,323.4$ & $8,843.0$ & $12,021.6$ & $3,298.8$ & $2,429.7$ \\
\hline 25 & 363.0 & 777.0 & $1,208.7$ & $1,154.8$ & 639.9 & $1,329.1$ & $1,114.3$ & $5,276.0$ & $8,551.7$ & $22,640.6$ & $2,845.8$ & $2,756.9$ \\
\hline 26 & 444.4 & $1,656.3$ & $2,805.1$ & $2,693.8$ & $1,279.7$ & $3,124.5$ & $2,885.1$ & $13,641.4$ & $20,185.8$ & $17,731.8$ & $5,238.7$ & $3,812.1$ \\
\hline 27 & 189.4 & 313.4 & 374.8 & 740.8 & 559.9 & 831.6 & 815.6 & $3,889.5$ & $2,156.0$ & $3,043.0$ & $2,425.5$ & $2,014.8$ \\
\hline 28 & 128.8 & 295.3 & 363.4 & 661.4 & 320.0 & 652.1 & 915.8 & $2,437.7$ & $2,063.4$ & $1,402.5$ & $2,902.2$ & $2,599.4$ \\
\hline 29 & 281.9 & 530.0 & 913.2 & 919.0 & $1,039.7$ & $1,017.3$ & $1,203.8$ & $4,329.6$ & $4,570.1$ & $15,327.5$ & $2,163.8$ & $2,184.0$ \\
\hline 30 & 59.1 & 160.8 & 127.0 & 170.1 & 400.0 & 316.5 & 615.2 & 766.4 & 567.1 & 291.2 & $2,042.5$ & $2,126.4$ \\
\hline
\end{tabular}

Table 3. Least significance difference (LSD) test results for groups of analyzed urban tree appraisal formulas, appraiser experience, and between appraisers in central Chile.

\begin{tabular}{|c|c|c|c|c|c|c|c|c|}
\hline Formula & $\begin{array}{l}\text { Average } \\
\text { ranking }\end{array}$ & $\begin{array}{l}\text { Homogenous } \\
\text { groups }\end{array}$ & $\begin{array}{l}\text { Appraiser } \\
\text { group }\end{array}$ & $\begin{array}{l}\text { Average } \\
\text { ranking }\end{array}$ & $\begin{array}{l}\text { Homogenous } \\
\text { groups }\end{array}$ & Appraiser & $\begin{array}{l}\text { Average } \\
\text { ranking }\end{array}$ & $\begin{array}{l}\text { Homogenous } \\
\text { groups }\end{array}$ \\
\hline Danish method & 537.2 & A & Senior & $1,408.4$ & $\mathrm{~J}$ & Appraiser S2 & $1,340.5$ & $\mathrm{~L}$ \\
\hline French method & 809.1 & $\mathrm{~B}$ & Junior & $1,472.6$ & $\mathrm{~K}$ & Appraiser S1 & $1,360.1$ & L M \\
\hline CTLA & 977.8 & $\mathrm{C}$ & & & & Appraiser J1 & $1,419.8$ & L M N \\
\hline Swiss method & $1,076.3$ & $\mathrm{CD}$ & & & & Appraiser S3 & $1,429.1$ & L M N \\
\hline Peñalolén method & $1,095.4$ & $\mathrm{D}$ & & & & Appraiser J2 & $1,476.2$ & M N \\
\hline Italian method & $1,298.0$ & E & & & & Appraiser J3 & $1,493.3$ & $\mathrm{~N}$ \\
\hline COPIMA & $1,382.1$ & $\mathrm{E}$ & & & & Appraiser J4 & $1,501.1$ & $\mathrm{~N}$ \\
\hline Tedesco method & $1,752.2$ & $\mathrm{~F}$ & & & & Appraiser S4 & $1,503.8$ & $\mathrm{~N}$ \\
\hline Norma Granada & $1,892.4$ & G & & & & & & \\
\hline Burnley method & $2,086.5$ & $\mathrm{H}$ & & & & & & \\
\hline Helliwell method & $2,106.4$ & $\mathrm{H}$ & & & & & & \\
\hline STEM & $2,272.6$ & I & & & & & & \\
\hline
\end{tabular}


evident, as the formulas are ranked according to the monetary value obtained. The Danish, French, and CTLA Methods are located in the lower area, while the Helliwell, Burnley and STEM Methods in the upper area.

The results of the Kruskal-Wallis test (Table 4) show results where each formula was analyzed separately, thus allowing for an evaluation of the formula by different appraisers. The Danish, Tedesco, Burney, and Helliwell Methods did show statistically significant differences between appraisers $(P<0.05)$.

In general, results also show very different values for each tree using the same formula and different appraisers. For example, Table 2 shows that the extreme average values that correspond to two trees in the Municipality of Talca. Tree \#13, a Ginkgo biloba, scored the maximum value using the Helliwell Method (USD \$40,347), locating it at the top of the ranking and corresponding to a locally emblematic specimen of more than 100-years-old, while the minimum was awarded to Tree \#19, a Betula pendula, which was characterized as an old tree with reduced-intermediate vigor (USD \$27) using the CTLA formula, and is located at the bottom of the value estimates. However, most importantly, researchers found disparate appraisal values according to individual appraisers and by their experience groups (Figure 1). The average value for each tree fluctuated between USD $\$ 13,823$ and USD $\$ 636$, with the maximum value obtained by Tree \#13 and with a minimum rating for Tree \#30, a Catalpa bignonioides located in Concepción. These same trends in valuation estimates have been reported by Watson (2002), Contato-Carol et al. (2008), Ponce-Donoso et al. (2009; 2012; 2013), and Grande-Ortiz et al. (2012).

Table 4. Kruskal-Wallis test results for 12 different urban tree appraisal formulas in central Chile.

\begin{tabular}{lll}
\hline Formula & Statistical & Probability \\
\hline Danish method & 30.44 & 0.000 \\
French method & 1.52 & 0.982 \\
CTLA & 3.03 & 0.883 \\
Swiss method & 7.06 & 0.423 \\
Peñalolén method & 0.10 & 1.000 \\
Italian method & 2.38 & 0.936 \\
COPIMA & 1.14 & 0.992 \\
Tedesco method & 18.00 & 0.012 \\
Norma Granada & 1.29 & 0.989 \\
Burnley method & 15.24 & 0.033 \\
Helliwell method & 19.50 & 0.007 \\
STEM & 6.93 & 0.437 \\
\hline
\end{tabular}

In general, researchers found that the first quartile the highest average values were presented by the Helliwell, Burnley, and STEM formulas; with a value of USD \$7,342 for the Helliwell Method. Second were Norma Granada (of USD \$1,760), Tedesco, and COPIMA. In the third quartile the formulas were the Tedesco,

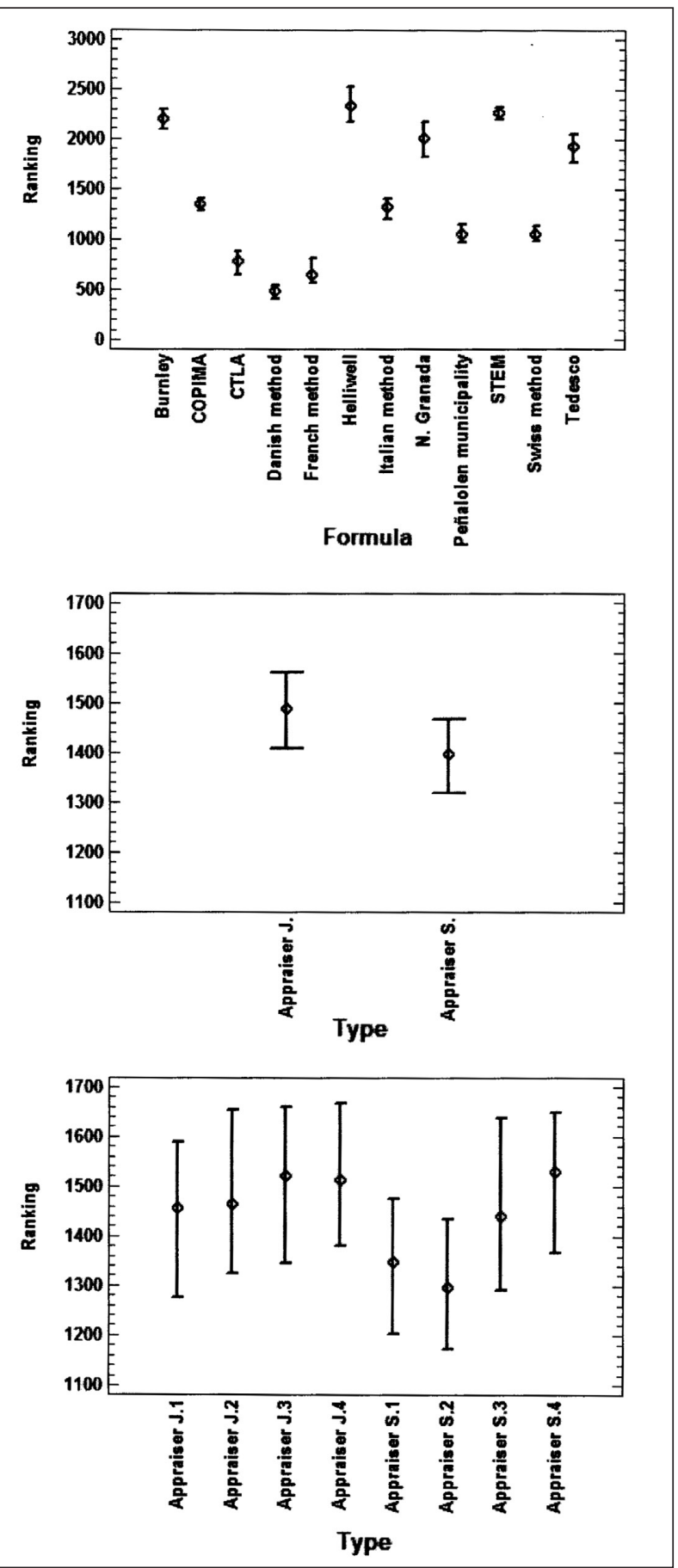

Figure 1. Median, standard error, and ranking for formulas, appraiser group, and between appraisers. 
the Italian, Swiss, and Peñalolén formulas, with an average of USD $\$ 574$ for first one. In the bottom quartile, with the lowest values, were the CTLA, French, and Danish (USD \$161) formulas.

\section{DISCUSSION}

The results show that in using average monetary values, the Danish Method delivered low values, with an average of USD \$207, and a median USD $\$ 161$. The Swiss Method, as reported by Contato-Carol et al. (2008), resulted in the fourth lowest average value (USD \$548). The Burnley had the fourth highest average value (USD \$2,688) in contrast to what was reported by Ponce-Donoso et al. (2012). However, findings were consistent with these same authors regarding the CTLA and French Methods (Contato-Carol et al. 2008; PonceDonoso et al. 2013). In regards to the two Chilean formulas analyzed (i.e., Peñalolén Method and COPIMA), the findings were similar to those reported by Ponce-Donoso et al. (2009; 2012; 2013). These authors found that intermediate values were obtained, and the COPIMA continued to perform better with regards to the Chilean formulas.

A wide dispersion in the average rankings were also found (Table 3; Figure 1), with differences of more than fourfold between the lowest and highest value, as exemplified by the Danish and French Methods with regards to the STEM formula, due to the fact they present statistically significant differences from the rest of the formulas in Groups A, B, and I. The French Method was followed by the CTLA, Swiss, and Peñalolén formulas, whereas mean values were displayed by the Italian Method and COPIMA, forming a group with no statistical differences in their medians. The Tedesco and Norma Granada formulas displayed slightly higher intermediate values. Finally, those with higher average values were the Burnley, Helliwell, and STEM formulas; the first two forming a group with no statistical differences in their medians (Group H; Table 3). Overall, the results showed a wide variability in the studied formulas, whose differences in the valuation were due to their structural characteristics, and just as important, appraiser variability (GrandeOrtiz et al. 2012; Ponce-Donoso et al. 2013).

When comparing the results and overall formula performance of the current study to those reported by Watson (2002), researchers discovered similar findings exhibiting high variability. While the Helliwell Method displayed the highest values in Watson's (2002) study, the current findings show values from the Danish Method were followed by Helliwell, Tedesco, and Burnley Methods; and further, they showed no statistical significant difference when analyzed separately according to appraiser $(P<0.05$; Table 4$)$. The remaining formulas did show differences between appraisers, with the greatest in the Peñalolén, COPIMA, French, Italian, and Swiss methods $(P>0.8)$; a finding pointed out by Watson (2002) when comparing these same formulas. Conversely, the CTLA, Italian, French, Norma Granada, COPIMA, and Peñalolén methods showed the least variability, indicating that differences between appraisers were minimal.

Considering that all formulas were parametric, their application in these three cites delivered both low and high values (e.g., CTLA and STEM Methods) that differed with other studies (Watson 2002; Contato-Carol et al. 2008). It is not clear, however, which factor or parameter, either multiplicative or additive, is most influential and has the greatest weight in the total appraised value. Future research could analyze the sensitivity of each individual parameter separately, so as to recognize the weight they have in formula performance. Further, research is also needed on other key variables that could be used in these appraisal formulas, such as demographic characteristics (e.g., average monetary income of the city's population), as well feasibility and viability of applying the formula.

Researchers were not able to identify with any degree of certainty which of the formulas was best at assessing each tree, as the analyzed formulas performed dissimilarly. However, when analyzing the range and median of the ranking as performance criteria, the Norma Granada, CTLA, and COPIMA formulas performed well, relative to the others (Figure 1), by achieving low average values, which are relevant for the context in which the study took place. This was also corroborated by the lower degree of dispersion [i.e., a high probability (Table 4)] and a median showing a distribution of values indicating a fair appraisal. The formulas that had the highest values were the Helliwell and Burnley; 
findings that are similar to what were reported in other studies (Watson 2002; Ponce-Donoso et al. 2012; Ponce-Donoso et al. 2013). Researchers also note that STEM formulas exhibited high values, although with only a moderate dispersion.

In comparing the experience level of appraisers (i.e., SG and JG), significant statistical differences were found, though the difference was minimal if the average ranking is considered (Table 3; Figure 1). This indicates further training could reduce the probability of statistical differences. When comparing all appraisers, in one group, statistically significant differences were found, thereby resulting in three different groups. Nevertheless, rankings were not ordered in function of the group's experience (Table 3; Figure 1), thus the individuals' experience would not be a differentiating factor, statistically speaking. As shown in Table 3, Group L incorporated three appraisers with experience and one without, Group $M$ included two experienced and two inexperienced appraisers, and Group $\mathrm{N}$ had two experienced and four inexperienced appraisers (Table 3). Thus, the lower average value was obtained by two senior appraisers (S1 and S2), and the highest valuation was also obtained by one of these, while all JG appraisers are located within the ranking (Table 3).

On the other hand, the role of experts in appraisal procedures, provided a distinctive element in the valuations, where the most experienced appraisers consistently tended to get lower values in their valuation (Cullen 2005), which was contrary to the norm that experience is a requirement for the appraisal of the tree (Price 2003; Tyrväinen et al. 2003). This shows the need for a minimum level of instruction to obtain the professional skills necessary for implementing a formula, considering that these appraisers had more of an ad hoc professional training. Therefore, when considering this particular case, the Danish Method, French Method, CTLA Method, Swiss Method, Peñalolén Method, Italian Method, and COPIMA (excluding Norma Granada, Helliwell, Burnley, Tedesco, and STEM) have no statistically significant differences between the type of appraisers or among the eight appraisers.

\section{CONCLUSIONS}

Overall, researchers found statistically significant differences between the medians of the studied formulas, among types of appraisers, and among individual appraisers. This indicates that the valuation of urban trees depends preferably on the specific formula used (i.e., type and its constituent variables) as well as the appraiser's experience; aspects that coincide with studies by Watson's (2002), Contato-Carol et al. (2008), Grande-Ortiz et al. (2012) and Ponce-Donoso et al. (2012; 2013). The formulas that presented the best comparative performance as defined by dispersion and location of the median, were the Helliwell, Norma Granada, Tedesco, Burnley, and CTLA Methods, while the lower performance were found in the French, Swiss, Danish, and STEM Methods.

Researcher note that when the appraisers were organized into three homogeneous groups, findings show that experience did not seem to be a factor that differed statistically. Group N was the largest group, composed of $75 \%$ of the appraisers, all JG, and only two SG (Table 3). Group L included four appraisers and only one having junior experience, while Group $M$ was composed of two each (Table 3). Again, the experience would be a determining factor when it comes to valuation of urban trees (Grande-Ortiz et al. 2012).

The results show that the use of parametric formulas is recommended when appraising urban trees in international contexts. This was observed by the ability of formulas to discriminate the value of trees, resulting in the graphic dispersion of monetary values presented in the rankings (i.e., high dollar amount for higher value tree, medium monetary value for mean tree, and lowest for those with a lower value monetary values). In this study, these features were identified in the CTLA, Helliwell, and Norma Granada Methods.

Acknowledgments. The authors thanks to Fondo Nacional de Desarrollo Científico y Tecnológico of Chile (FONDECYT) Project 1130264 for funding this project. 


\section{LITERATURE CITED}

AEPJP (Asociación Española de Parques y Jardines Públicos, ES). 2007. Norma Granada. Método para valoración de árboles y arbustos ornamentales, tercera edición. Madrid, Spain. 53 pp.

Bernatzky, A. 1978. Tree ecology and preservation. Elsevier Scientific Publishing Company, New York, New York, U.S.

Caballer, V. 1999. Valoración de Árboles. Mundi-Prensa, Madrid, Spain. 247 pp.

Chueca, J. 2001. La Norma Granada: Un método de valoración económica de los árboles ornamentales. Accessed 22 October 2007. <www.drac.com/pers/chueca/ Granada.htm>

Conover, W. 1999. Practical nonparametric statistics, third edition. John Wiley \& Sons Inc., New York, New York, U.S. 584 pp.

Contato-Carol, M.L., E. Ayuga-Tellez, and M.A. Grande-Ortiz. 2008. A comparative analysis of methods for the valuation of urban trees in Santiago del Estero, Argentina. Spanish Journal Agriculture Research 6:314-352.

Cordell, H., L. Anderson, C. Berisford, Y. Berisfrod, L. Biles, P. Black, and R. DeGraaf, et al. 1984. Urban Forestry, Section 16. In: K. Wenger. Forestry Handbook. Washington, second edition. Wiley Interscience 887-983 pp.

CTLA (Council of Tree \& Landscape Appraisers). 2000. Guide for Plant Appraisal, ninth edition. International Society of Arboriculture, Champaign, Illinois, U.S. 143 pp.

Cullen, S. 2005. Tree appraisal: Chronology of North American industry guidance. Journal of Arboriculture 31:157-162.

Cullen, S. 2007. Putting a value on trees-CTLA guidance and methods. Arboricultural Journal 30:21-43.

Dobbs, C., F. Escobedo, and W.C. Zipperer. 2011. A framework for developing urban forest ecosystem services and goods indicators. Landscape and Urban Planning 99:196-206.

Escobedo, F.J., D.C. Adams, and N. Timilsina. 2015. Urban forest structure effects on property value. Ecosystem Services 12:209-217.

Fabbri M. 1989. Metodi di stima del valore delle piante arboree ornamentali. Acer 2:15-19.

Ferraris, P. 1984. Note sulla valutaziones del soprasoulo arbóreo di parchi e giardini. Journal Flortécnica 11:11-15.

Flook, R. 1996. A Standard Tree Evaluation Method-STEM. Journal of the New Zealand Institute of Horticulture 1:29-35.

Grande-Ortiz, M., M. Ayuga-Tellez, and M. Contato-Carol. 2012. Methods of tree appraisal: A review of their features and application possibilities. Arboriculture \& Urban Forestry 38:130-140.

Haase, D., N. Larondelle, E. Andersson, M. Artmann, S. Borgström, J. Breuste, and E. Gomez-Baggethum, et al. 2014. A quantitative review of urban ecosystem service assessments: Concepts, models, and implementation. Ambio 43:413-433.

Harris, J.A. 2007. Jurisdiction determines the appraisal or valuation method. Tree and Landscape appraisal. Accessed 11 November 2011. <www.landscapeeconomics.com>

Hegedüs, A., M. Gaál, and R. Bérces. 2011. Tree appraisal methods and their application first results in one Budapest's districts. Applied Ecology and Environmental Research 9:411-423.

Helliwell, R. 2008. Amenity valuation of trees and woodlands. Arboricultural Journal 31:161-168.

i-Tree. 2012. Tools for assessing and managing forests and community trees. <www.itreetools.org/eco/index.php>
Kirk, R. 1995. Experimental Design: Procedures for the Behavioral Sciences, third edition. Pacific Grove: Brooks/Cole Publishing Company and International Thompson Publishing Company, California, United Sates. 921 pp.

Konijnendijk, C., S. Syaka, T. Randrup, and L. Schipperijn. 2004. Urban and peri-urban forestry in the development context: Strategic and implementation. Journal of Arboriculture 30:269-276.

Leal, L., D. Biondi, and R. Rochadelli. 2008. Investment on urban trees in the city of Curitiba: An approach based on the land income theory. Scientia Forestalis 36:141-149.

Moore, G.M., and T. Arthur. 1992. Amenity tree evaluation: A revised method. In: T. Arthur (Ed.). The Scientific Management of Plants in the Urban Environment. Proceedings of the Burnley Centenary Conference. Centre for Urban Horticulture. Melbourne, Australia. pp. 166-171.

NCL (National Congress Library). 2013. Districts Statistical and Communal Reports 2013. Accessed 22 October 2012. <www. bcn.cl>

Neilan, C. 2010. CAVAT. Capital asset value for amenity trees. Full Method: User's guide. London Tree Officers Association. 11 pp.

Östrberg, J., and J. Sjögren. 2016. The linear index of tree appraisal (LITA) model for economic valuation of large urban trees in Sweden. Arboriculture \& Urban Forestry 42:21-30.

Petersen, K., and T. Straka. 2011. Specialized discount cash flow analysis formulas for valuation of benefits and cost of urban trees and forest. Arboriculture \& Urban Forestry 37:200-206.

Ponce-Donoso, M., L. Moya, and O. Bustos-Letelier. 2009. Evaluation of formula for the appraisal of urban trees in municipalities of Chile. Scientia Forestalis 37:321-329.

Ponce-Donoso, M., O. Vallejos-Barra, and G. Daniluk-Mosquera. 2012. Comparación de fórmulas chilenas e internacionales para valorar el arbolado urbano. Bosque 33:69-81.

Ponce-Donoso, M., O. Vallejos-Barra, G. Daniluk-Mosquera, and C. Avilés-Palacios. 2013. Comparison of seven Chilean Formulas for urban tree appraisal. Agrociencia 47:723-737.

Price, C. 2003. Quantifying the aesthetic benefits of urban forestry. Urban Forest \& Urban Greening 1:123-134.

Randrup, T.B. 2005. Development of Danish model for plant appraisal. Journal of Arboriculture 31:114-123.

Roy, S., J. Byrne, C. Pickering. 2012. A systematic quantitative review of urban tree benefits, costs, and assessment methods across cities in different climatic zones. Urban Forestry \& Urban Greening 11:351-363.

Sarajevs, V. 2011. Street tree valuation systems. Forestry Commission. Research Note 8. Edinburgh, Scotland. 6 pp.

Tyrväinen, L. 2001. Economic valuation of urban forest benefits in Finland. Journal of Environmental Management 62:75-92.

Tyrväinen, L., H. Silvennoinen, and O. Kolehmainen. 2003. Ecological and aesthetic value in urban forest management. Urban Forest \& Urban Greening 1:135-149.

Watson, G. 2001. A study of CTLA formula values. Journal of Arboriculture 27:289-297.

Watson, G. 2002. Comparing formula methods of tree appraisal. Journal of Arboriculture 28:11-18. 


\author{
Mauricio Ponce-Donoso (corresponding author) \\ Faculty of Forest Science \\ Universidad de Talca \\ Avenida Lircay s/n, Casilla 747 \\ Talca, Chile \\ mponce@utalca.cl
}

Óscar Vallejos-Barra

Faculty of Forest Science

Universidad de Talca

Avenida Lircay s/n, Casilla 747

Talca, Chile

Francisco J. Escobedo

Functional and Ecosystem Ecology Unit

Universidad del Rosario

Km $26 N^{\circ} 63 B-48$

Bogotá D.C., Colombia

Résumé. L'établissement de la valeur monétaire des arbres urbains peut être réalisée en recourant à des formules, une pratique courante dans de nombreux pays. Cette étude compare douze formules de type paramétrique: la méthode d'évaluation d'agrément des arbres et des boisés (Amenity Valuation of Tree and Woodlands) de Helliwell, la méthode standard dévaluation des arbres (Standard Tree Evaluation Method ou STEM), la méthode française, la méthode italienne, la méthode Tedesco également italienne, la Norma Granada espagnole, la méthode de la surface terrière du CTLA, la méthode australienne Burnley, la méthode danoise, la méthode suisse et deux formules chiliennes utilisées dans les municipalités de Concepción, La Pintana et Maipú (la méthode COPIMA) et la méthode Peñalolén. Ces formules ont alors été mises en pratique sur 30 arbres situés à Santiago, à Talca et à Concepcion, Chili.

Les chercheurs ont recruté huit évaluateurs répartis en deux groupes selon le niveau d'expérience senior ou junior. Les différences statistiques furent déterminées à l'aide du test de variation non paramétrique de Kruskal-Wallis, tandis que le test de différence minimale de Fisher a été utilisé pour distinguer des groupes homogènes. Les résultats montrent une large variation des valeurs qui étaient élevées pour les arbres " symboliques ou typiques » et basses pour les arbres jeunes ou de moindre vigueur.

La formule utilisée, le niveau d'expérience des évaluateurs et les distinctions parmi les évaluateurs ont dégagé respectivement neuf, deux et trois groupes. La plus faible valeur des arbres évalués a été obtenue les méthodes danoise et française, tandis que les valeurs les plus élevées ont été obtenues avec les formules de Burnley, de Helliwell et de STEM. Bien qu'il y ait des différences dans la valeur des arbres selon chacun des évaluateurs, en comparant la différence entre les évaluateurs, les chercheurs ont constaté que cellesci n'étaient pas causées par les niveaux d'expérience variés de ces derniers. Considérant la grande disparité des valeurs obtenues, les auteurs de l'étude ne peuvent recommander une ou des formule (s) spécifique (s) pour l'évaluation des arbres urbains, puisque les résultats dépendront des variables d'intérêt utilisées dans les formules et de leur mise en application et usage.

Zusammenfassung. Eine monetäre Evaluation durch urbane Baumbewertungen kann durch Formeln durchgeführt werden, was in vielen Ländern eine übliche Praxis ist. Diese Studie vergleicht zwölf Formeln parametrischen Typs: Attraktivitäts- Evaluation von Bäumen und Waldstücken (Helliwell), Standard Baum Evaluation Methode (STEM), Französische Methode, Italienische Methode, Tedesco, Norma Granada, Stamm-Ersatz Formel (CTLA), Burnley
Methode, Dänische Methode, Schweizer Methode, und zwei chilenische Formeln, die in den Verwaltungen von Concepción, La Pintana, und Maipú (COPIMA Methode) verwendet werden und die Peñalolénische Methode (Chile). Diese Formeln wurden dann bei 30 Bäumen in Santiago, Talca, und Concepcion, Chile, angewendet.

Die Forscher beauftragten acht Gutachter, unterteilt in zwei Gruppen, angepasst an Senior- und Juniorgrad ihrer Erfahrung. Statistische Differenzen wurden durch den Kruskal-Wallis Test nicht-parametrischer Varianzen bestimmt, während Fishers Test der am wenigsten signifikanten Differenzen verwendet wurde, um homogene Gruppen zu identifizieren. Die Ergebnisse zeigen eine weite Streuung der Werte, die hoch waren für "emblematische" Bäume und niedrig für junge Bäume oder Bäume mit niedriger Vitalität.

Formel, Typ des Gutachters (Erfahrungsstand) und Differenzen zwischen den Gutachtern formten neun, beziehungsweise zwei oder drei Gruppen. Die am geringsten bewerteten Bäume erhielt man durch die Dänische und Französische Methode, während die höchsten Werte durch die Burnley, Helliwell, und STEM Formel erzielt wurden. Obwohl Differenzen im Baumwert in Bezug auf den Erfahrungslevels der Gutachter auftraten, wenn man die Differenzen zwischen den Gutachtern verglich, fanden die Forscher heraus, dass es nicht an den unterschiedlichen Erfahrungshorizonten lag. Unter Berücksichtigung der weiten Spanne an herausgefundenen Werten, können die Autoren dieser Studie keine spezifische Formel für die Bewertung von urbanen Bäumen empfehlen, weil die Ergebnisse von einer Reihe von Variablen des Interesses innerhalb der Formeln und der beabsichtigten Applikation und Verwendung abhängig sind.

Resumen. La valoración monetaria de árboles urbanos puede realizarse con fórmulas, una práctica común en muchos países. Este estudio compara doce fórmulas de tipo paramétrico: Amenity Valuation of Tree and Woodlands (Helliwell), Método Estándar de Evaluación de Árboles (STEM), Método Francés, Método Italiano, Tedesco, Norma Granada, Fórmula de Reemplazo de Tronco (CTLA), Método Burnley, Método danés, Método suizo, y dos fórmulas chilenas utilizadas en los municipios de Concepción, La Pintana y Maipú (Método COPIMA), y el Método Peñalolén. Luego se aplicaron las fórmulas a 30 árboles ubicados en Santiago, Talca y Concepción, Chile. Los investigadores utilizaron ocho evaluadores divididos en dos grupos, de acuerdo con la experiencia de nivel junior y superior. Las diferencias estadísticas se determinaron usando el test de Kruskal-Wallis de varianza no paramétrica, mientras que el test de Fisher se utilizó para identificar grupos homogéneos. Los resultados muestran una amplia dispersión de valores que fueron altos para árboles "emblemáticos" y bajos para árboles jóvenes o de bajo vigor. La fórmula, el tipo de tasadores y las diferencias entre tasadores formaron nueve, dos y tres grupos, respectivamente. Los árboles de menor valor se obtuvieron utilizando el método danés y francés, mientras que los valores más altos se obtuvieron con las fórmulas Burnley, Helliwell y STEM. Aunque hubo diferencias en el valor de los árboles según el tipo de tasador, al comparar la diferencia entre los evaluadores, los investigadores encontraron que estos no se debían al nivel de experiencia. Dada la amplia gama de valores encontrados, los autores del estudio no pueden recomendar ninguna fórmula específica para evaluar árboles urbanos, ya que los resultados dependerán de las variables de interés utilizadas en las fórmulas, su aplicación y uso previstos. 